\title{
The first described turtle beetles from Eocene Baltic amber, with notes on fossil Chelonariidae (Coleoptera: Byrrhoidea)
}

\author{
Vitalii I. Alekseev ${ }^{1,2}$, Jerit Mitchell ${ }^{3}$, Ryan C. McKellar ${ }^{4,5,6}$, Mauricio Barbi ${ }^{3}$, Hans C. E. Larsson ${ }^{7}$, and \\ Andris Bukejs ${ }^{8}$ \\ ${ }^{1}$ Shirshov Institute of Oceanology, Russian Academy of Sciences, Nahimovskiy prospekt 36, Moscow 117997, Russia \\ ${ }^{2}$ Kaliningrad Regional Amber Museum, Marshal Vasilevskii square 1, Kaliningrad 236016, Russia \\ ${ }^{3}$ Physics Department, University of Regina, Regina, SK, S4S 0A2, Canada \\ ${ }^{4}$ Royal Saskatchewan Museum, 2445 Albert St., Regina, SK, S4P 4W7, Canada \\ ${ }^{5}$ Biology Department, University of Regina, Regina, SK, S4S 0A2, Canada \\ ${ }^{6}$ Department of Ecology \& Evolutionary Biology, University of Kansas, Lawrence, Kansas 66045, USA \\ ${ }^{7}$ Redpath Museum, McGill University, Montreal, QC, H3A 0C4, Canada \\ ${ }^{8}$ Institute of Life Sciences and Technologies, Daugavpils University, Vienības 13, Daugavpils 5401, Latvia
}

Correspondence: Andris Bukejs (carabidae@inbox.lv)

Received: 23 October 2020 - Revised: 16 December 2020 - Accepted: 23 December 2020 - Published: 10 February 2021

\begin{abstract}
Chelonariidae, or turtle beetles, are rarely represented in the fossil record. Two new extinct species of this thermophilous coleopteran family, Chelonarium andabata Alekseev and Bukejs sp. nov. and Ch. dingansich Alekseev and Bukejs sp. nov., are described and illustrated from Eocene Baltic amber using X-ray micro-computed tomography (micro-CT). They are the first formally described species of turtle beetles from Eocene Baltic amber and the first known European representatives of this family. Based on modern habitats of the group, the presence of the plants with which their larvae are associated (epiphytic orchids) is proposed in the Eocene amber forest. The Eocene Florissant Formation fossil Chelonarium montanum Wickham, 1914, which was originally placed within Chelonariidae, is discussed based on its original description, and placement as incertae sedis within Byrrhoidea is proposed for this compression fossil (http://zoobank.org/References/ C2EE164D-59DD-42FE-937D-B01C78DCD228, last access: 8 February 2021).
\end{abstract}

\section{Introduction}

The coleopteran superfamily Byrrhoidea consists of 12 extant families (Ślipiński et al., 2011), and half of them have been reported from Eocene Baltic amber (Klebs, 1910; Lars- son, 1978; Kirejtshuk and Azar, 2013; Alekseev, 2019). Six fossil species were described from this Lagerstätte within Elmidae, Limnichidae and Ptilodactylidae (Bollow, 1940; Pütz et al., 2004; Bukejs et al., 2015; Alekseev and Jäch, 2016; Hernando et al., 2018), but the three remaining families (Byrrhidae, Heteroceridae and Chelonariidae) are still awaiting further attention from researchers to complete formal taxonomic descriptions from the amber deposit.

Chelonariidae are rarely represented in the fossil record. Until now, only two fossil species have been described as belonging to this family: (1) a dubious chelonariid fossil (see critical note in the Discussion) - Chelonarium montanum Wickham, 1914 - from the Eocene Florissant Formation (Wickham, 1914) and (2) Eochelonarium belle Kirejtshuk in Kirejtshuk and Azar (2013), a monotypic chelonariid beetle genus from Lower Cretaceous Lebanese amber (Kirejtshuk and Azar, 2013). Reports of chelonariid beetles from Eocene Baltic amber have been made in the recent literature (Kirejtshuk and Azar, 2013; Alekseev, 2019), but even generic assignment of the specimens is never mentioned in these works. In the present paper, the first turtle beetle species from Eocene Baltic amber of the Kaliningrad Region (western Russia) is described and illustrated using X-ray microcomputed tomography (micro-CT). 


\section{Material and methods}

The material examined is deposited in the following collections:

- the Palaeontology Collection of the Royal Saskatchewan Museum (Regina, Saskatchewan, Canada) [RSKM specimen number prefix]

- the collection of the Museum of Amber Inclusions, University of Gdańsk (Poland) [MAIG].

The X-ray micro-CT observations of specimen RSKM_P3000.141 were conducted at the McGill University Integrated Quantitative Biology Initiative in Montreal, Canada, using a Zeiss Xradia 520 Versa system. Scans used an X-ray beam with an energy level of $60 \mathrm{kV}$ and $83 \mu \mathrm{A}$, an LE6 filter, a source-to-sample distance of $38 \mathrm{~mm}$, and sample to detector distance of $333 \mathrm{~mm}$ for phase contrast. Tomographic slices were generated from 1601 rotational steps through $180^{\circ}$ of rotation, with a $0.4 \times$ objective and $5 \mathrm{~s}$ exposure times. Images were binned $(2 \times 2 \times 2)$, with a resolution of $7.0 \mu \mathrm{m}$. The specimen fit within a single field of view, and a 40 min warmup scan was conducted. Dragonfly Pro (ver. 2020.1) software was used for segmentation and 3D visualization, as well as for producing videos of scan data.

The X-ray micro-CT observations of specimen 6696 [MAIG] were conducted at Daugavpils University, Daugavpils, Latvia, using a Zeiss Xradia 510 Versa system. Scans were performed with a polychromatic X-ray beam with $40 \mathrm{kV}$ of energy and $3 \mathrm{~W}$ of power. Sample-detector distance was set to $24 \mathrm{~mm}$, and source-to-sample distance to $44.5 \mathrm{~mm}$. Tomographic slices were generated from 1601 rotation steps through a $360^{\circ}$ rotation using a $4 \times$ objective, and exposure time during each projection was set to $7 \mathrm{~s}$. Variable exposure was set to two times at the thickest part of the amber to achieve similar amounts of photon throughput over the whole sample. Acquired images were binned $(2 \times 2 \times 2)$, giving a voxel size of $4.4 \mu \mathrm{m}$. Since specimen length was bigger than the field of view for selected parameters, we carried out image acquisition using an automated vertical stitch function for three consecutive scans with identical scanning parameters. Between those scans field of view was set to overlap $41 \%$ of data between adjacent fields of view. Prior to the full scan a 14 min warmup scan was conducted in which source-sample and sample-source distances were changed to accommodate the whole specimen in the field of view. For the warmup scan the rotational steps were reduced to 201, binning was set to 4 and exposure time was set to $1 \mathrm{~s}$. Images were imported into the Dragonfly Pro (ver. 2020.1) software platform for interactive segmentation and 3D visualization.

Photographs of specimen RSKM_P3000.141 were taken using a Visionary Digital imaging system, consisting of a Canon MP-E $65 \mathrm{~mm}$ macrophotography lens, as well as a Dun Inc. microphotography system, consisting of Mitutoyo
$5 \times$ and $10 \times$ Plan Apo objective lenses on a modified Canon EF $200 \mathrm{~mm}$ lens, attached to a Canon EOS 5D camera. The camera was on an automated camera lift with studio flash lighting. Supplementary images were taken with a Leica MZ12.5 stereomicroscope equipped with a Canon T6i camera. Extended depth of field at high magnifications was achieved by combining multiple images from a range of focal planes using Helicon Focus 6.8.0 software, and the resulting images were edited to create figures using Adobe Photoshop CS5.

Photographs of specimen 6696 [MAIG] were taken using a Canon 70D camera with a macro lens (Canon MP-E $65 \mathrm{~mm}$ ). Extended depth of field at high magnifications was achieved by combining multiple images from a range of focal planes using Helicon Focus v. 6.0.18 software, and the resulting images were edited to create figures using Adobe Photoshop CS5.

The following references were used for the generic attribution and comparison with recent and fossil taxa: Méquignon (1932), Mandl (1967), Paulus (1969), Satô (2001), Ivie (2002), Leschen and Early (2004), Kirejtshuk and Azar (2013), and Beutel and Leschen (2016).

\section{Systematic palaeontology}

Superfamily Byrrhoidea Latreille, 1804

Family Chelonariidae Blanchard, 1845

Genus Chelonarium Fabricius, 1801

\section{Remarks}

The studied amber specimens possess the combination of characteristics unequivocally corresponding to the family Chelonariidae: biconvex body shape (i.e. fusiform in lateral view), head declined under semicircular pronotum and not visible in dorsal view, tarsomere 3 of the pentamerous tarsi with long membranous lobe, pronotum and scutellum distinctly crenulate basally, pro- and mesosternum with deep groove-like excavation for reception of the basal antennomeres, ventral side of body with depressions for reception of legs, and anterior edge of pronotum curving downwards and posteriad.

Based on the presence of the above-mentioned characteristics and the following set of characteristics, both chelonariid specimens under consideration from Baltic amber are similar to Chelonarium representatives from the Recent fauna and can be considered as congeneric: (1) pronotum margined anteriorly and laterally with complete sharp carina (in contrast to pronotum without such completely surrounding sharp carina in Brounia Sharp or Pseudochelonarium Pic), (2) hypomera with depressions for reception of forelegs (absent in Brounia, only weakly developed in Eochelonarium Kirejtshuk), and (3) protibiae flattened (narrow in Eochelonarium and Brounia) and with spinose outer margin. 
Chelonarium andabata Alekseev and Bukejs sp. nov. urn:lsid:zoobank.org:act:27596D45-C0C2-430BA0AE-35DCF5FB116C

Figs. 1-5, 8b

\section{Derivatio nominis}

The specific epithet "andabata" is a Latin word meaning "a type of gladiator who fought blind because of a restrictive helmet" and refers to the strongly declined head of the beetle, which is concealed from above. The specific epithet is used as a noun in apposition.

\section{Type material}

Holotype: collection number "RSKM_P3000.141”, "Holotype/Chelonarium andabata sp. nov./Alekseev and Bukejs des. 2021" [red printed label] [RSKM]; adult, male. Almost complete beetle (right antennomeres 10-11 lacking) included in a transparent, yellow amber piece with approximate dimensions of $8 \mathrm{~mm} \times 16 \mathrm{~mm}$ and a maximum thickness of $8 \mathrm{~mm}$; preserved without supplementary fixation. The dorsal part of the specimen is partially obscured by milky amber. Syninclusions are absent.

\section{Type stratum}

Baltic amber from Eocene amber-bearing Blue Earth layers; a predominantly Bartonian age has been interpreted for the extinct central European resin-producing forests (Bukejs et al., 2019).

\section{Type locality}

Yantarny settlement (formerly Palmnicken), Sambian (Samland) Peninsula, Kaliningrad Region, Russia.

\section{Description}

Measurements: body length $5.6 \mathrm{~mm}$, maximum body width $3.2 \mathrm{~mm}$; pronotum length $1.2 \mathrm{~mm}$, maximum pronotum width $2.5 \mathrm{~mm}$; elytra length $4.3 \mathrm{~mm}$, maximum combined elytra width $3.2 \mathrm{~mm}$.

Body ovoid, widely oval, biconvex; total body length / maximum body width equal to 1.75 ; integument unicolorous dark brown (as preserved). Pubescence unicolorous and dark: dorsum covered with short, semierect setae in moderate density; elytral vestiture uniform, simple, without any trichome-like structures, setae almost straight to slightly curved; setae at elytral lateral sides slightly stouter; venter and legs with dense, short recumbent setae.

Head declined, not visible from above, rounded pentagonal, slightly convex; densely punctate; punctures round and small, distance between punctures equal to $0.2-0.5 \times$ diameter of one puncture. Clypeus not distinct, frontoclypeal su- ture absent. Eyes small, entire, almost round, slightly convex, finely facetted, without interfacetal setation; interocular frontal distance equal to about $2 \times$ diameter of one eye. Antennal insertions hidden. Antennae rather long; scape hidden, rounded and short; pedicel and antennomeres 3-11 flattened; antennomere 3 longest, antennomere 4 shortest; antennomeres 2-3 and 11 elongate, antennomeres 5-10 triangular in outline. Relative length ratios of antennomeres $1-11$ equal to $1.5: 3: 7: 0.7: 1.8: 2: 2: 2.2: 2.2: 2: 3.4$.

Pronotum transverse, $2.1 \times$ as wide as long, widest at base, with fine and dense punctation. Posterior angles of pronotum acute. Anterior edge of pronotum almost semicircular in dorsal view; posterior edge bisinuate and crenulate. Pronotum margined anteriorly and laterally with sharp, raised carina dividing pronotum into upper (moderately convex dorsally) and lower (inclined posteriad) parts. Lower pronotal area (between prominent anterior carina and posterior edge of concealed head) wider than protibial width. Pro- and mesosternum with deep, elongate, intercoxal median excavation for reception of basal antennomeres. Hypomeron excavated to receive profemora; meso- and metaventrite with excavations for receiving meso- and metafemora as well as tibiae.

Scutellum subpentagonal, almost as long as wide. Elytra moderately convex, widely oval, about $1.4 \times$ as long as combined width; distinctly wider than pronotal posterior margin, about $3.6 \times$ as long as pronotum. Elytral punctation irregular, dense and round along sides, sparser and finer on disc, distance between punctures equal to $0.3-3.0 \times$ diameter of one puncture, interspaces flat. Epipleura narrow, reaching abdominal ventrite 1 . Metepisternum wide, about $2 \times$ as wide as maximum epipleural width, with dense, small punctation. Metaventrite slightly convex laterally, with almost flat disc; densely covered with small punctation; distance between punctures smaller than diameter of one puncture; interspaces slightly convex; discrimen distinct in anterior half of metaventrite.

Legs rather short, flattened; densely covered with small punctures; distance between punctures smaller than diameter of one puncture. All coxae distinctly separated; proand mesocoxae widely oval, slightly transverse, about 1.3$1.4 \times$ as wide as long; metacoxae narrow, strongly transverse, excavate, with short metacoxal plates and with triangular outer edge. Femora and tibiae subequal in length; proand mesofemur comparatively wider than metafemur. Tibiae narrower than femora, protibia about $0.5 \times$ as wide as profemur, mesotibia about $0.5 \times$ as wide mesofemur, metatibia about $0.6 \times$ as wide as metafemur; protibia spinose along inner margin. Tarsi 5 segmented, tarsomere 3 with long membranous lobe ventrally, tarsomere 4 minute. Relative length ratios of mesotarsomeres $1-5$ equal to $15: 10: 7: 4: 25$. Pretarsal claws with denticle basally.

Abdomen with five visible ventrites; abdominal sutures entire, slightly concave; ventrite 5 simple, with widely rounded, semicircular apical margin; finely and densely punctate; distance between punctures equal to $0.5-1.0 \times$ di- 

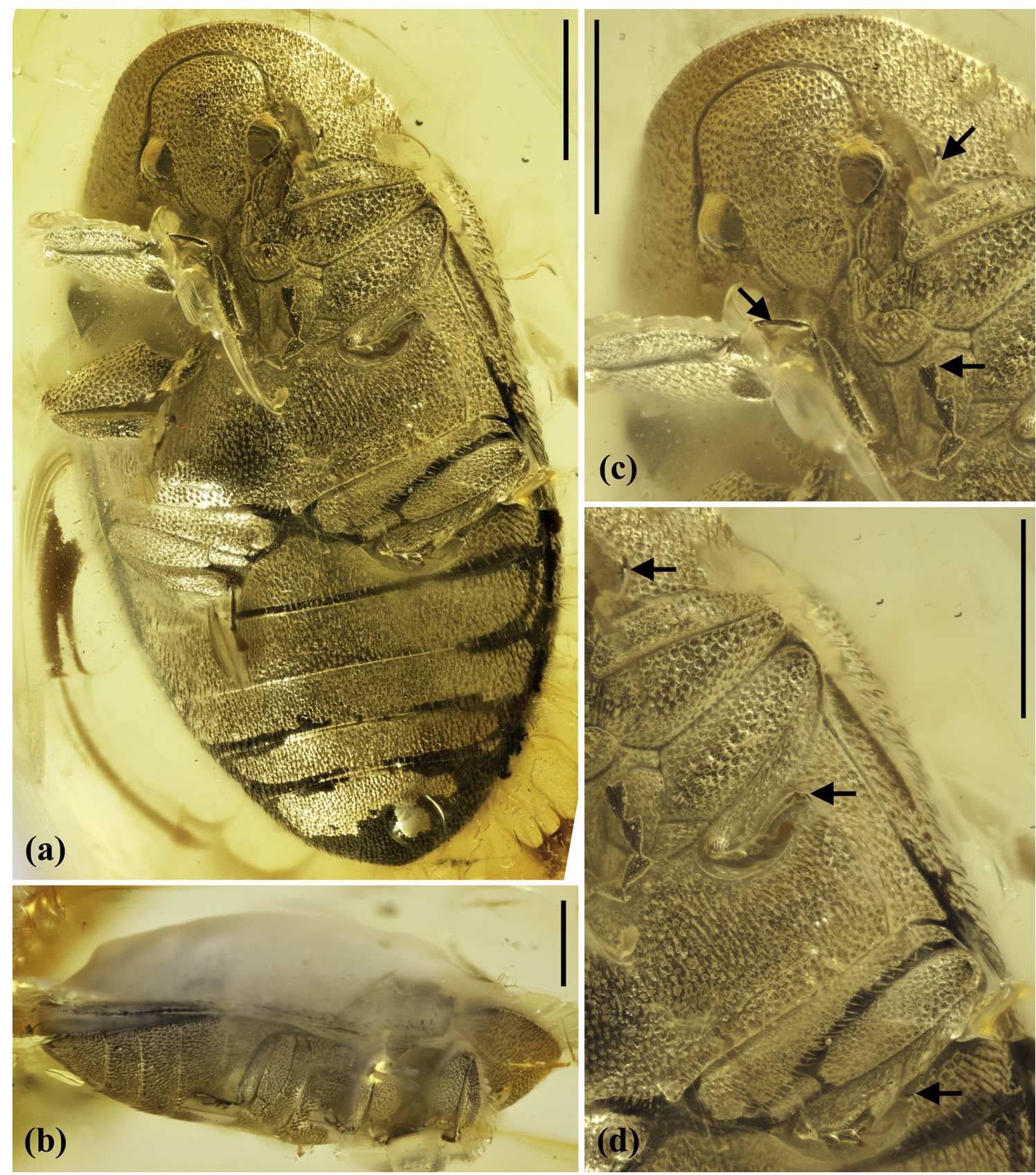

Figure 1. Photomicrographs of Chelonarium andabata Alekseev and Bukejs sp. nov., holotype, RSKM_P3000.141 [RSKM]: (a) ventral habitus view; (b) right lateral habitus view; (c) detail of head with antenna (horizontal arrow) and protarsi (inclined arrows) in ventral view; and (d) detail of legs in ventral view with pro-, meso-, and metatarsus indicated by horizontal arrows (from top to bottom of view). Scale bars $=1.0 \mathrm{~mm}$.

ameter of one puncture. Relative length ratios of abdominal ventrites $1-5$ equal to $7: 4.5: 4: 3.5: 6.5$ (medially).

Aedeagus robust, with widely rounded base and gradually narrowed apically (Fig. 5).

\section{Differential diagnosis}

The genus Chelonarium is very species-rich but poorly documented: it is in need of revision for many of its inadequately illustrated and briefly described species. The Eocene taxon Ch. andabata sp. nov. is similar to one Recent North American chelonariid species, Ch. lecontei Thomson, in its general antennal structure, but it differs in having smaller eyes (inte- 


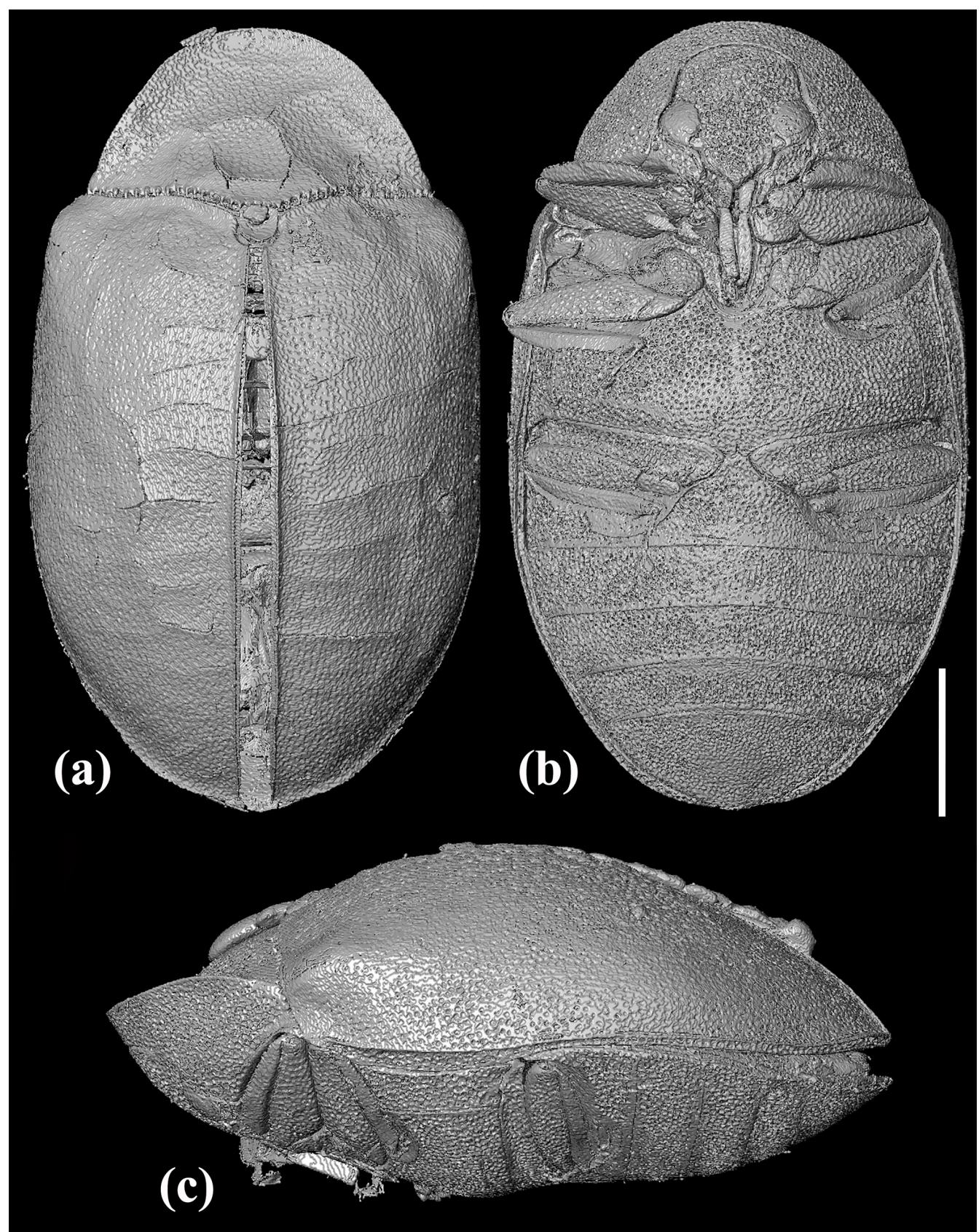

Figure 2. X-ray micro-CT renderings of Chelonarium andabata Alekseev and Bukejs sp. nov., holotype, RSKM_P3000.141 [RSKM], habitus: (a) dorsal view, (b) ventral view and (c) left lateral view. Scale bar $=1.0 \mathrm{~mm}$.

rocular distance in $C h$. lecontei is slightly less than one eye diameter), denser head punctation and uniform elytral vestiture (without maculae). The newly described fossil species can be distinguished from the westernmost Palaearctic $C h$. vartianae Mandl (Afghanistan) based on having a pronotum without transverse impression. Chelonarium andabata sp. nov. clearly differs from $C h$. ornatum Klug in its ratio of four basal antennomere lengths; it differs from Ch. kurosawai Satô in possessing unicolorous elytra; and it differs from $C h$. beauvoisi Latreille, Ch. convexum Méquignon and Ch. cupreum Méquignon in its smaller body size. The combination of characteristics mentioned in the species description, additional characteristics of body part ratios, and details of vestiture and punctation should distinguish the new fossil species from all Recent congeners. 


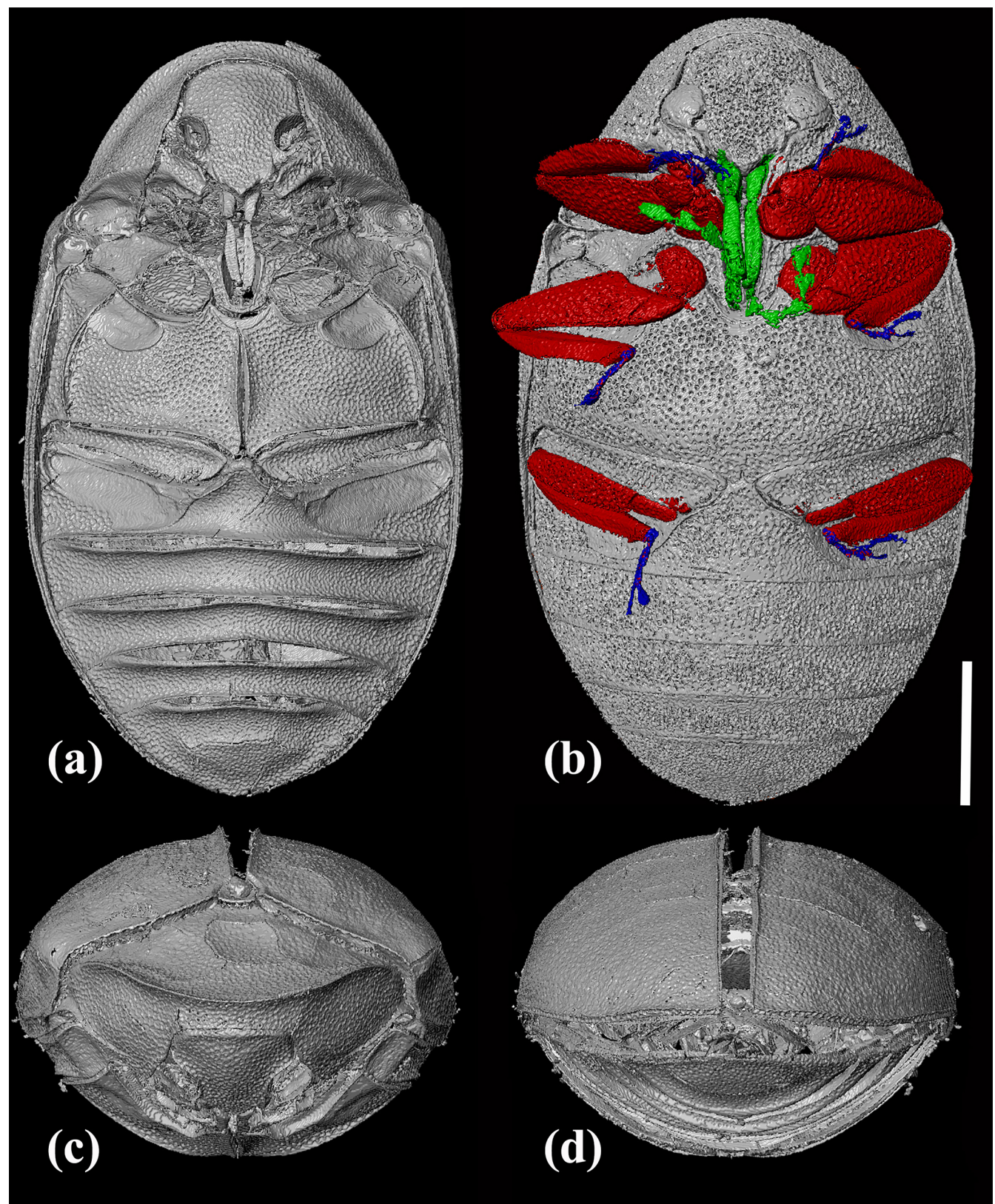

Figure 3. X-ray micro-CT renderings of Chelonarium andabata Alekseev and Bukejs sp. nov., holotype, RSKM_P3000.141 [RSKM], habitus: (a) ventral view without legs, showing depressions for legs reception; (b) ventral view with antennae and legs in different colours; (c) frontal view; and (d) caudal view. Scale bar $=1.0 \mathrm{~mm}$.

Chelonarium dingansich Alekseev and Bukejs sp. nov. urn:lsid:zoobank.org:act:CE0A8F66-563F-49958AD4-F7846E1FE27D

Figs. 6-7, 8a

\section{Derivatio nominis}

The specific epithet "dingansich" is derived from the German word combination "Ding an sich" (in English: "thing in itself"), a well-known philosophic concept introduced by Immanuel Kant. The species name is dedicated to this famous Königsberg (now Kaliningrad)-native Prussian philosopher and thinker, in the run-up to the 300-year anniversary of his birth in 2024. The name is used as a noun in apposition.

\section{Type material}

Holotype: collection number "6696" [MAIG] (ex. coll. Jonas Damzen JDC 7210), "Holotype/Chelonarium dingansich sp. 


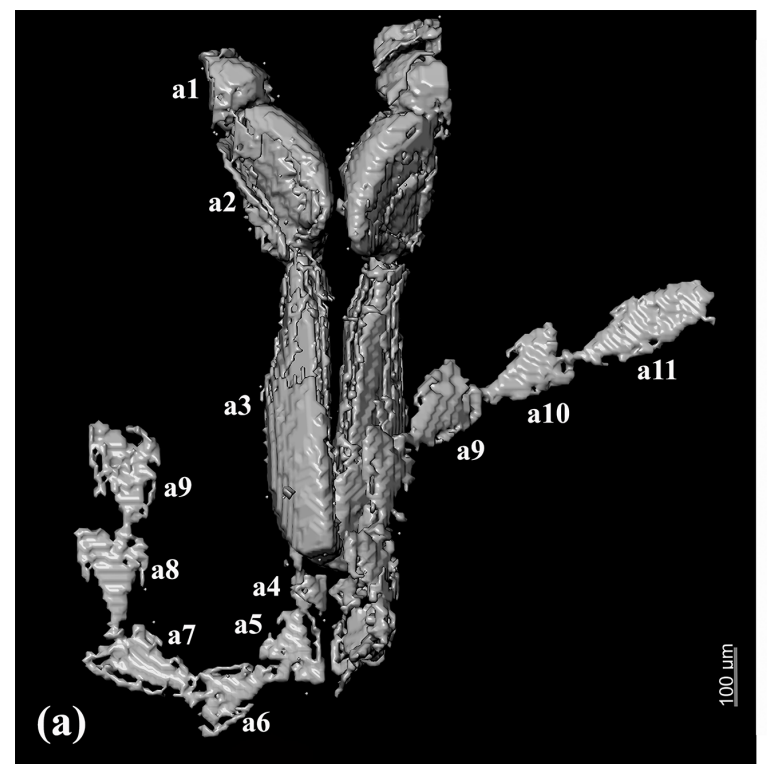

(b)

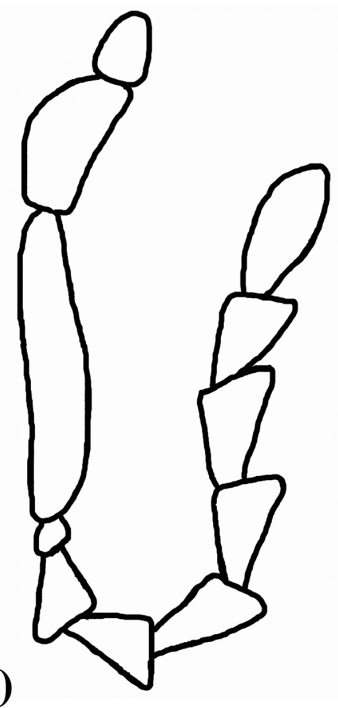

Figure 4. Antennae of Chelonarium andabata Alekseev and Bukejs sp. nov., holotype, RSKM_P3000.141 [RSKM]: (a) X-ray micro-CT rendering and (b) reconstruction. Abbreviations: a1-a11 - antennomeres 1-11 respectively.

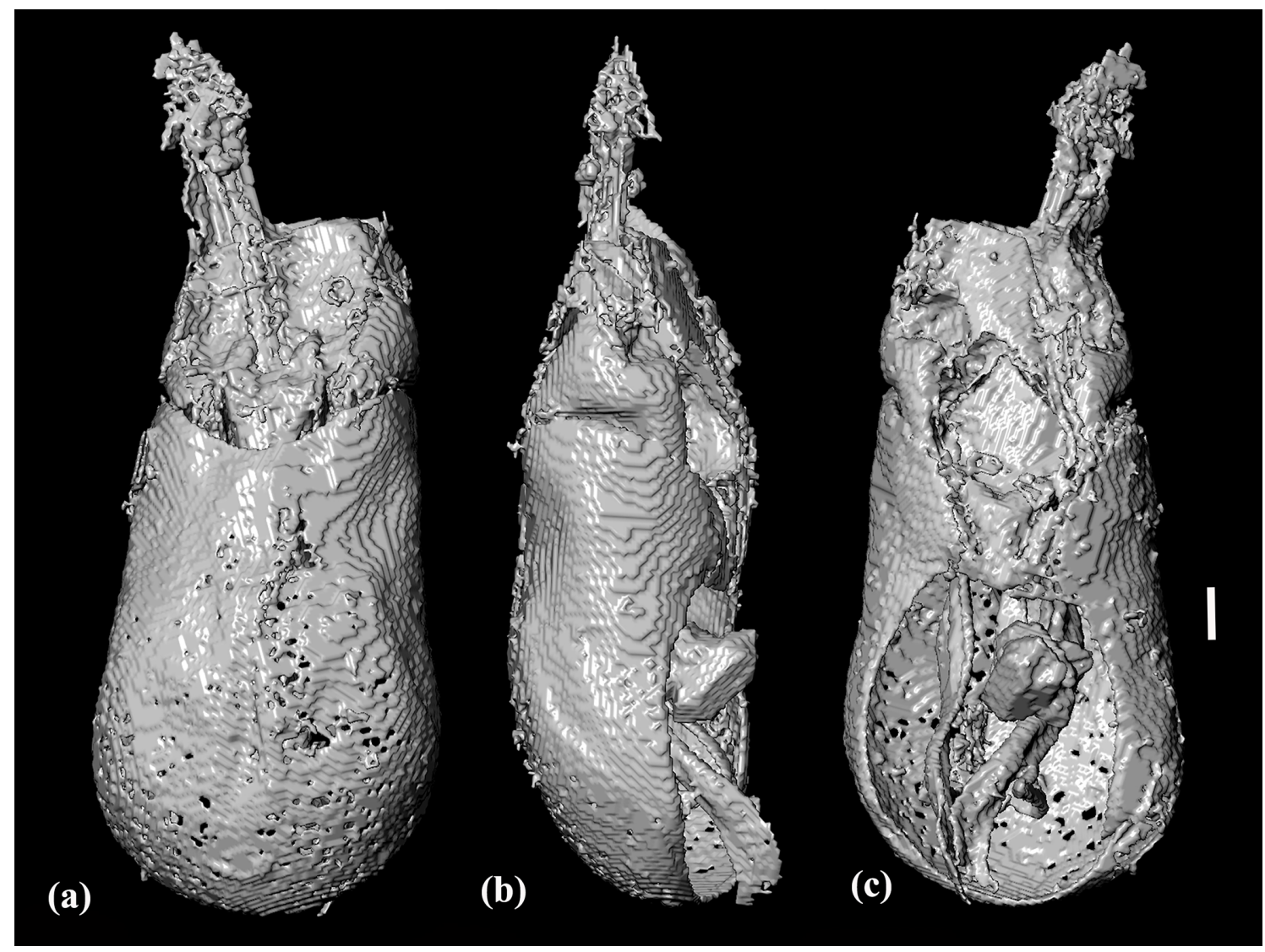

Figure 5. X-ray micro-CT renderings of Chelonarium andabata Alekseev and Bukejs sp. nov., holotype, RSKM_P3000.141 [RSKM], aedeagus: (a) dorsal view, (b) lateral view and (c) ventral view. Scale bar $=0.1 \mathrm{~mm}$. 

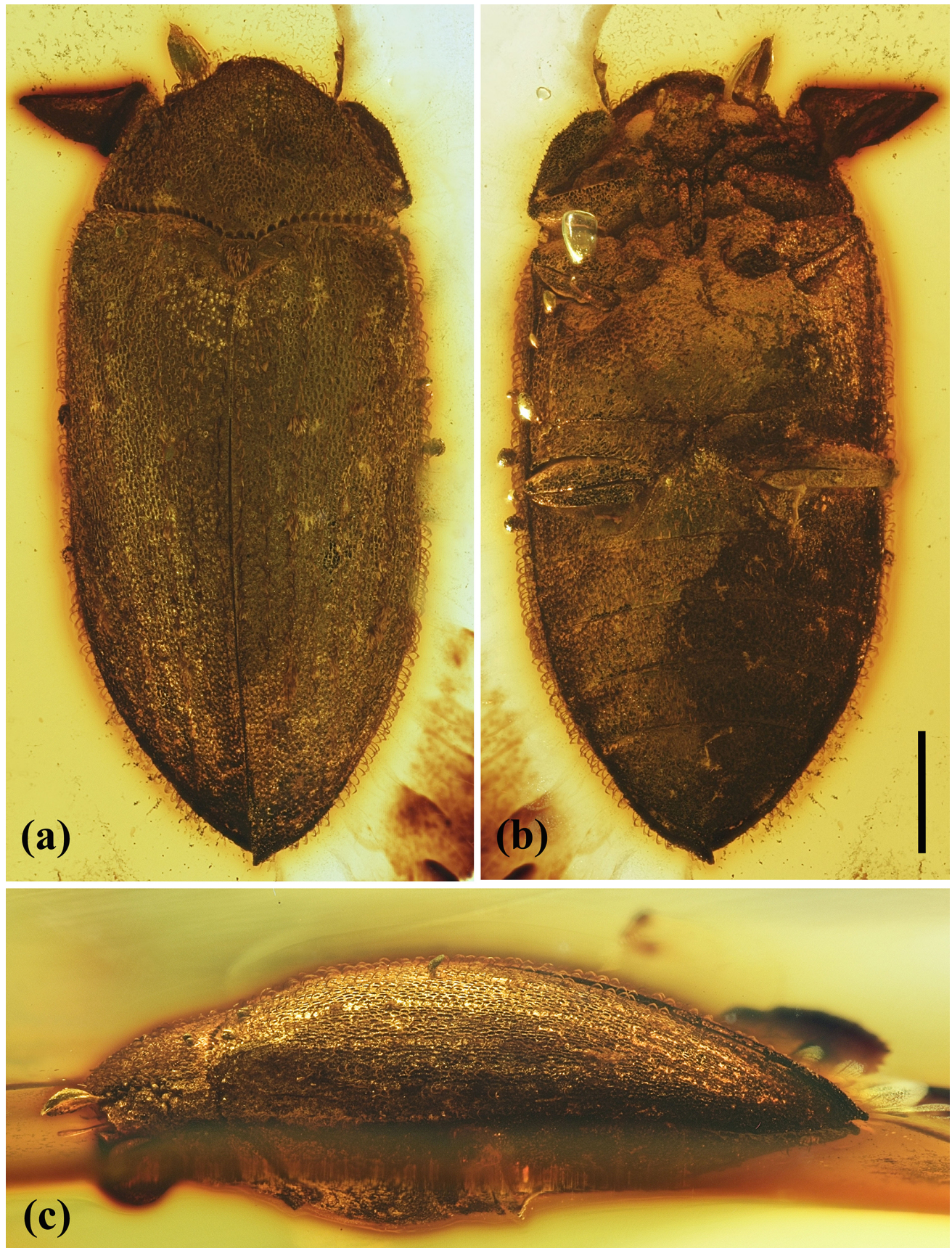

Figure 6. Photomicrographs of Chelonarium dingansich Alekseev and Bukejs sp. nov., holotype, 6696 [MAIG], habitus: (a) dorsal view, (b) ventral view and (c) left lateral view. Scale bar $=1.0 \mathrm{~mm}$.

nov./Alekseev and Bukejs des. 2021" [red printed label] [MAIG]; adult, sex apparently female. Almost complete beetle (antennomeres $4-11$ of both antennae lacking) included in a transparent, yellow amber piece with approximate dimensions of $40 \mathrm{~mm} \times 20 \mathrm{~mm}$ and a maximum thickness of $10 \mathrm{~mm}$; preserved without supplementary fixation. Syninclusions: four very small stellate trichomes and a few small gas vesicles.

\section{Type stratum}

Baltic amber from Eocene amber-bearing Blue Earth layers; a predominantly Bartonian age has been interpreted for the extinct central European resin-producing forests (Bukejs et al., 2019). 


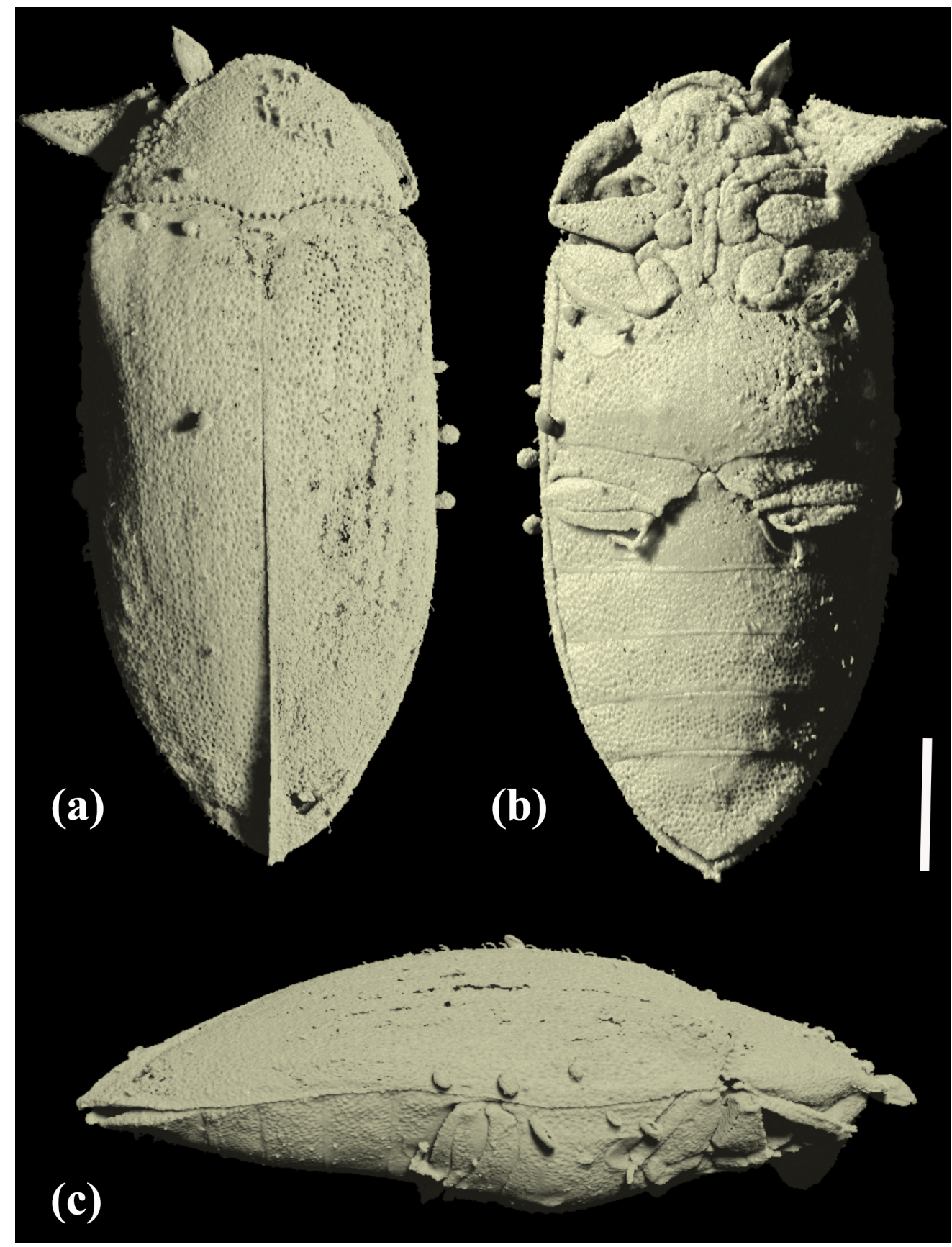

Figure 7. X-ray micro-CT renderings of Chelonarium dingansich Alekseev and Bukejs sp. nov., holotype, 6696 [MAIG], habitus: (a) dorsal view, (b) ventral view and (c) right lateral view. Scale bar $=1.0 \mathrm{~mm}$.

\section{Type locality}

Yantarny settlement (formerly Palmnicken), Sambian (Samland) Peninsula, Kaliningrad Region, Russia.

\section{Description}

Measurements: body length $6.2 \mathrm{~mm}$, maximum body width $2.7 \mathrm{~mm}$; pronotum length $1.4 \mathrm{~mm}$, maximum pronotum width $2.3 \mathrm{~mm}$; elytra length $4.9 \mathrm{~mm}$, maximum combined elytra width $2.7 \mathrm{~mm}$.

Body elongate oval, biconvex; total body length / maximum body width equal to 2.3 ; integument unicolorous dark brown (as preserved). Pubescence dark, with small patches of denser and paler setae on elytral disc: dorsum covered with short, semierect setae in moderate density; lateral sides of elytra and pronotum with slightly 

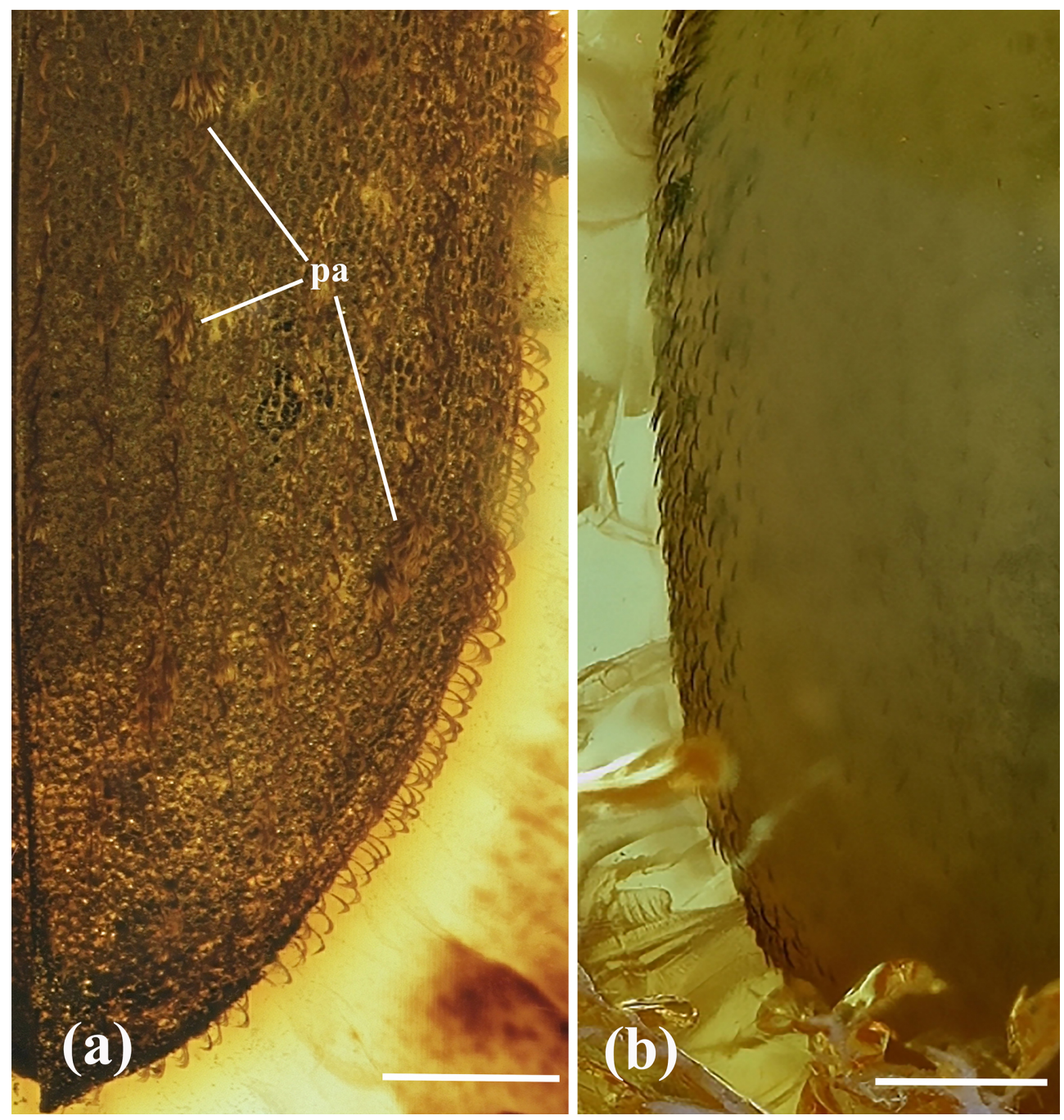

Figure 8. Elytral vestiture and setation shape in fossil Chelonarium: (a) Ch. dingansich Alekseev and Bukejs sp. nov., right elytron, and (b) Ch. andabata Alekseev and Bukejs sp. nov., left elytron. Scale bars $=0.5 \mathrm{~mm}$. Abbreviation: pa - patches of paler and denser setae.

longer, distinctly curved setae; elytral vestiture simple, without any trichome-like structures; venter and legs with dense, recumbent, almost straight setation, setae shorter than setae of dorsum.

Head declined, not visible from above, slightly convex; densely covered with small punctation; distance between punctures smaller than diameter of one puncture. Clypeus not distinct; frontoclypeal suture absent. Eyes small, entire, almost round, slightly convex, finely facetted, without interfacetal setation; interocular frontal distance equal to about $2 \times$ diameter of one eye. Antennal insertions hidden. Antennae rather long; scape hidden; pedicel short, about $0.4 \times$ as long as antennomere 3; antennomere 3 longest, flattened.

Pronotum transverse, $1.6 \times$ as wide as long, widest at base; densely covered with small punctuation; distance between punctures less than diameter of one puncture. Posterior angles of pronotum acute. Anterior edge of pronotum almost semicircular in dorsal view; posterior edge bisinuate and crenulate. Pronotum margined anteriorly and laterally, with sharp, raised carina dividing pronotum into upper (moderately convex dorsally) and lower (inclined posteriad) parts. Lower pronotal area, between prominent anterior carina and posterior edge of concealed head, wider than protibial width. Pro- and mesosternum with deep, elongate, intercoxal median excavation for reception of basal antennomeres. Hypomeron excavated to receive profemora; mesoand metaventrite with excavations for receiving meso- and metafemora and tibiae.

Scutellum subpentagonal, almost as long as wide, densely covered with semierect, pale setae. Elytra moderately convex, forming elongate oval about $1.9 \times$ as long as combined width; slightly wider than pronotal posterior margin, about $3.6 \times$ as long as pronotum. Elytral punctation irregular, small, dense and round, with distance between punctures less than 
diameter of one puncture; interspaces almost flat. Epipleura narrow, reaching abdominal ventrite 1 . Metepisternum wide, about $2 \times$ as wide as epipleural maximum width; with dense, small punctation. Metaventrite slightly convex laterally, with almost flat disc; densely covered with small punctation; distance between punctures smaller than diameter of one puncture; interspaces slightly convex; discrimen distinct in anterior half of metaventrite.

Legs rather short, flattened; densely covered with small punctures; distance between punctures smaller than diameter of one puncture. All coxae distinctly separated; procoxa nearly round; mesocoxa oval; metacoxa narrow, strongly transverse, excavate, with short metacoxal plates and with triangular outer edge. Femora and tibiae subequal in length; pro- and mesofemora comparatively wider than metafemur. Tibiae narrower than femora, protibia about $0.6 \times$ as wide as profemur, mesotibia about $0.3 \times$ as wide mesofemur, metatibia about $0.6 \times$ as wide as metafemur; protibia spinose along inner margin. Tarsi 5 segmented, tarsomere 3 apparently with membranous lobe ventrally, tarsomere 4 minute. Tarsal claws with denticle basally.

Abdomen with five visible ventrites; abdominal sutures entire, slightly concave to almost straight; ventrite 5 simple, with widely triangular apical margin; finely and densely punctate; distance between punctures equal to $0.5-1.0 \times$ diameter of one puncture. Relative length ratios of abdominal ventrites $1-5$ equal to $6: 4: 4: 3.5: 7$ (medially).

\section{Differential diagnosis}

Chelonarium dingansich sp. nov. differs from $C h$. andabata sp. nov. in possessing longer and distinctly curved setae on elytral and pronotal lateral sides (setae comparatively shorter and almost straight in Ch. andabata sp. nov.); an elytral disc with small patches of paler setae (without small patches of paler setae in Ch. andabata sp. nov.); a widely rounded, semicircular apical margin of abdominal ventrite 5 (widely triangular in Ch. andabata sp. nov.); and a distinctly more elongate oval body: less transverse pronotum, $1.6 \times$ as wide as long $(2.1 \times$ as wide as long in Ch. andabata sp. nov.), and more elongate elytra, $1.9 \times$ as long as combined width $(1.4 \times$ as long as combined width in Ch. andabata sp. nov.).

\section{Remarks}

The sex of the examined specimen is determined based on micro-CT results. There is no sclerotized aedeagus-like structure present inside the abdomen; therefore, the specimen appears to be female.

\section{Discussion}

\subsection{Zoogeographical and ecological notes}

Chelonariidae are a small coleopteran family, which comprises three Recent genera with about 300 described species that are predominantly distributed in tropical regions (Beutel and Leschen, 2016). Brounia Sharp is restricted to New Zealand; Pseudochelonarium Pic (consisting of two subgenera, Pseudochelonarium and Neochelonarium Méquignon) occurs in New Guinea, India, eastern and southeastern Asia; and Chelonarium Fabricius is mainly found in the neotropics but also occurs in Asia and Australia (Leschen and Early, 2004; Beutel and Leschen, 2016). In the present-day Palaearctic region, Chelonariidae are restricted to the southernmost periphery of eastern Asia (Afghanistan; Bhutan; China: Hainan; India; Japan; Taiwan) and represented by four species of Chelonarium and seven species of Pseudochelonarium (Satô, 2016). No representatives of the family are known from modern Europe or Africa.

Chelonariid larvae are probably detritus feeders in moistto-dry litter on the ground. Their known habitats include the bases of trees, orchids and other plants; the refuse heaps of ants or termite galleries in branches; and under the bark of dead trees (Ivie, 2002). A preference for the roots of orchids and tree epiphytes, as well as myrmecophilous or termitophilous tendencies, has been suggested (Beutel and Leschen, 2016); however, detailed observations of larval feeding habits are lacking. Interestingly, European Eocene amber-producing forests were thermophilous, humid mixed forest communities that grew in a climate thought to have had low seasonality (Alekseev, 2017; Bogri et al., 2018, 2020). Both of the larval habitats that have been recorded for Recent congeners of the newly described fossil species have also been documented for this Lagerstätte: (1) the oldest orchid fossil known at present was recently described from Baltic amber on the basis of orchid pollinaria (Poinar and Rasmussen, 2017), and (2) the fauna of termites and ants in the Baltic amber forest was diverse and species-rich (e.g. Wheeler, 1915; Engel et al., 2007). A similar biology is tentatively suggested for Chelonarium andabata sp. nov. and $C h$. dingansich sp. nov., with the fossil taxa having been subcortical or inquiline in moist forest habitats with numerous overmatured trees and epiphytic orchids, and with an abundance of different termite and ant species.

The presence in Baltic amber of representatives belonging to an extant coleopteran genus often associated with epiphytic orchids may provide additional support for (1) the presence and comparative abundance of their host plants (Orchidaceae, possibly Epidendroideae, from tribes Dendrobieae and/or Epidendreae) in the Eocene amber forest and (2) the possible epiphytic nature of these orchids. Given the scarcity of data about Eocene orchids, and the indirect connection between these plants and fossil Chelonariidae, it will not be possible to establish their habitat connection with con- 
fidence until more extensive palaeobotanical research is conducted on the deposit or future syninclusion associations add support to the suggestion.

\subsection{Notes on family placement of Chelonarium montanum Wickham, 1914}

The first described fossil chelonariid - Chelonarium montanum Wickham, 1914 - originated from the Eocene Florissant Formation (Wickham, 1914) and was attributed to the family only tentatively - workers such as Carpenter (1992) have treated this material as a Recent genus of Coleoptera with doubtfully assigned species. The dubious placement of the Florissant imprint within Chelonariidae follows from the original description and drawing: there are no details of the venter, legs or antennae given in this work, and the specimen was assigned to the genus Chelonarium based on the hypothesis that "the thoracic front margin seems to have nearly or quite concealed the head during the life". Alternative placements for this fossil include within Buprestidae because it "has something the aspect of a Brachys" (Wickham, 1914, pp. 434-435), a buprestid, or within the family Ptilodactylidae or Psephenidae because of the specimen's visible basal crenulation of the pronotum. Both of these alternatives are reasonable and possible; hence, we suggest that the species Chelonarium montanum Wickham, 1914, should be placed in Byrrhoidea incertae sedis before the type specimen is re-examined and re-described. This leaves only three species currently recognized within the fossil record of Chelonariidae, including the two species described herein. It also means that the dubious record of the extant genus Chelonarium in the Eocene shale deposits can now be replaced by two definitive examples in Eocene amber, which preserve internal structures as fine as genitalia.

\subsection{Notes concerning multiple original spellings of the species epithet in the genus Eochelonarium Kirejtshuk in Kirejtshuk and Azar (2013)}

The only definitive fossil chelonariid species described before the present paper is based on a beetle that originated from Lower Cretaceous Lebanese amber, which was placed in the monotypic genus Eochelonarium Kirejtshuk (Kirejtshuk and Azar, 2013). Two main distinguishing characteristics from the original description support the idea that the beetle belongs to a unique genus within the family ("prothorax without clear excavate area for receipt of anterior legs" and "protibia very narrow and slightly curved"). However, the species-level naming of this fossil presents a minor problem. The beetle has two original spellings of the species epithet: Eochelonarium belle (Kirejtshuk and Azar, 2013, pp. 103, 116, 119) and Eochelonarium bellum (Kirejtshuk and Azar, 2013, pp. 116 and 118 in figure captions). This is evidently a lapsus calami, but both variants of the name are used more than once, and the correct variant is not entirely clear. According to the ICZN paragraph 32.2.1 (i.e. if a name is spelled in more than one way in the work in which it was established, then, except as provided otherwise in this article, the correct original spelling is that chosen by the first reviser), and the ICZN paragraph 24.2.3 (selection of correct original spellings), we decided the possible name confusion should be discussed and prevented. To the best of our knowledge, no published papers have used the name Eochelonarium bellum or Eochelonarium belle, and an electronic database (Clapham, 2014) included only the variant "Eochelonarium belle" without any comments. Consequently, we can act as the "first reviser" in this dubious case.

As it is stated in the original etymology, the epithet of this new species means "beautiful", "handsome", "goodlooking", "fine" and "pretty". The one variant is "belle", and the second is "bellum", both of which overlap this meaning to some extent. The word "belle" is a French adjective meaning "attractive, pretty, handsome etc." or a Latin adverb meaning "beautifully, attractively etc.". The word "bellum" in Latin as a substantive means "war", or it functions as an adjective for "beautiful, handsome etc." in a neutral case. Based on grammatical correctness of the species name, Eochelonarium bellum would be preferred, as an amendment to the grammatically incorrect "belle" variant. On the other hand, the name "belle" was used first in the paper (in the summary), was used as the name for the type species of the new genus (Kirejtshuk and Azar, 2013, p. 116) and was used by the author of the original description in an online catalogue of fossils (Kirejtshuk and Ponomarenko, 2014); meanwhile Eochelonarium bellum only appears in figure captions. On the basis of these arguments, we select the name Eochelonarium belle as correct and propose the use of the specific epithet as a noun in apposition.

Data availability. All material included in the paper is deposited in the Palaeontology Collection of the Royal Saskatchewan Museum (Regina, Saskatchewan, Canada) [RSKM] and in the collection of the Museum of Amber Inclusions, University of Gdańsk (Poland) [MAIG], and all data are included in the description. X-ray microtomography volume renderings of the habitus, habitus without legs, antennae and aedeagus of Chelonarium andabata sp. nov., holotype, RSKM_P3000.141 [RSKM], and habitus of Ch. dingansich sp. nov., holotype, 6696 [MAIG], are available as video supplements.

Video supplement. The videos are available at

- https://doi.org/10.5446/49584 (Mitchell et al., 2021a)

- https://doi.org/10.5446/49583 (Mitchell et al., 2021b)

- https://doi.org/10.5446/49582 (Mitchell et al., 2021c)

- https://doi.org/10.5446/49581 (Mitchell et al., 2021d)

- https://doi.org/10.5446/49580 (Bukejs and Kairišs, 2021). 
Author contributions. VIA and $\mathrm{AB}$ designed the study, identified specimens, performed systematic placement and prepared new species descriptions. HCEL performed micro-CT measurements. $\mathrm{JM}$ reconstructed micro-CT data and created volume renderings and 3D models of Chelonarium andabata sp. nov. with help from MB. VIA and $\mathrm{AB}$ drafted the discussion. RCM located and prepared the specimen and prepared photomicrographs of Chelonarium andabata sp. nov. and plates. All authors drafted the manuscript and contributed to the writing and discussion.

Competing interests. The authors declare that they have no conflict of interest.

Acknowledgements. The authors are sincerely grateful to Elżbieta Sontag (Museum of Amber Inclusions, University of Gdańsk, Poland) for the loan of interesting fossil specimens, to Kristaps Kairišs (Daugavpils University, Daugavpils, Latvia) and Rui Tahara (McGill University, Montreal, Canada) for assistance in $\mathrm{X}$-ray micro-computed tomography, and to Jonas Damzen (Vilnius, Lithuania) for assistance during our amber research and permission to use photographs of Chelonarium dingansich sp. nov. We thank two anonymous reviewers for their helpful comments and corrections to an earlier version of the manuscript.

Financial support. The study of Vitalii I. Alekseev was done with the support of the state assignment of IO RAS (theme no. 01492019-0013), Ryan C. McKellar received support from an NSERC Discovery Grant (2015-00681) and Jerit Mitchell received support through the Mitacs Accelerate Fellowship programme. This research was performed using infrastructure of the Integrated Quantitative Biology Initiative, funded by the Quebec government, McGill University, and Canadian Foundation of Innovation project 33122.

Review statement. This paper was edited by Florian Witzmann and reviewed by Bill Shepard and one anonymous referee.

\section{References}

Alekseev, V. I.: Coleoptera from the middle-upper Eocene European ambers: generic composition, zoogeography and climatic implications, Zootaxa, 4290, 401-443, https://doi.org/10.11646/zootaxa.4290.3.1, 2017.

Alekseev, V. I.: New extinct Eocene Coleoptera in Baltic amber of Friedhelm Eichmann's collection (Germany), Baltic Journal of Coleopterology, 19, 11-22, 2019.

Alekseev, V. I. and Jäch, M.: Electrolichas circumbalticus gen. et sp. nov. (Coleoptera: Byrrhoidea: Ptilodactylidae) from Baltic amber, the first anchytarsine toed-winged beetle described from Europe, Zootaxa, 4136, 593-599, https://doi.org/10.11646/zootaxa.4136.3.10, 2016.

Beutel, R. G. and Leschen, R. A. B.: 19.10 Chelonariidae Blanchard, 1845, in: Handbook of Zoology, Arthropoda: Insecta: Coleoptera, Beetles Volume 1: Morphology and Systematics
(Archostemata, Adephaga, Myxophaga, Polyphaga partim), 2nd Edn., edited by: Beutel, R. G. and Leschen, R. A. B., Walter de Gruyter GmbH, Berlin/Boston, 639-644, 2016.

Blanchard, C. E.: Histoire naturelle des insectes, traitant de leurs moeurs et de leurs métamorphoses en génêrale et comprenant une nouvelle classification fondée sur leurs rapports naturels, Tome deuxiéme, Firmin Didot frères, Paris, 1845.

Bogri, A., Solodovnikov, A., and Żyła, D.: Baltic amber impact on historical biogeography and palaeoclimate research: oriental rove beetle Dysanabatium found in the Eocene of Europe (Coleoptera, Staphylinidae, Paederinae), Pap. Palaeontol., 4, 433-452, https://doi.org/10.1002/spp2.1113, 2018.

Bogri, A., Solodovnikov, A., Kypke, J. L., and Żyła, D.: Baltic amber members of the extant Micrillus-Scymbalium lineage of the Paederinae rove beetles (Coleoptera, Staphylinidae) and their systematic and ecological significance, Invertebr. Syst., 34, 451473, https://doi.org/10.1071/IS19070, 2020.

Bollow, H.: Die erste Helmenide (Coleoptera, Dryopidae) aus Bernstein, Mitteilungen Münchener Entomologischen Gesellschaft, 30, 117-119, 1940.

Bukejs, A. and Kairišs, K.: Chelonarium dingansich Alekseev et Bukejs sp. nov., holotype, 6696 [MAIG], Xray micro-CT volume rendering of the habitus, TIB, https://doi.org/10.5446/49580, 2021

Bukejs, A., Alekseev, V. I., and Jäch, M.: The riffle beetles (Coleoptera: Elmidae) of the Eocene Baltic amber: Heterelmis groehni sp. nov. and Heterlimnius samlandicus (Bollow, 1940) comb. nov., Zootaxa, 3986, 452-460, https://doi.org/10.11646/zootaxa.3986.4.4, 2015.

Bukejs, A., Alekseev, V. I., and Pollock, D. A.: Waidelotinae, a new subfamily of Pyrochroidae (Coleoptera: Tenebrionoidea) from Baltic amber of the Sambian peninsula and the interpretation of Sambian amber stratigraphy, age and location, Zootaxa, 4664, 261-273, https://doi.org/10.11646/zootaxa.4664.2.8, 2019.

Carpenter, F. M.: Superclass Hexapoda, in: Treatise of Invertebrate Paleontology. Part R. Arthropoda 3-4, edited by: Kaesler, R. L., Geological Society of America, Boulder, 1-655, 1992.

Clapham, M.: Lebanese amber records in the Paleobiology Database, Fossilworks, available at: http://www.fossilworks.org/ cgi-bin/bridge.pl?a=taxonInfo\&taxon_no=289429 (last access: 15 September 2020), 2014.

Engel, M. S., Grimaldi, D. A., and Krishna, K.: A synopsis of Baltic amber termites (Isoptera), Stuttgarter Beiträge zur Naturkunde, Serie B (Geologie und Paläontologie), 372, 1-20, 2007.

Fabricius, J. C.: Systema eleutheratorum secundum ordines, genera, species adiectis synonymis, locis, observationibus, descriptionibus, Volume 1, Bibliopolii Academici, Kiliae, 1801.

Hernando, C., Szawaryn, K., and Ribera, I.: A new species of Platypelochares from Baltic amber (Coleoptera: Limnichidae), Acta Ent. Mus. Nat. Pra., 58, 17-20, https://doi.org/10.2478/aemnp-2018-0003, 2018.

Ivie, M. A.: 50. Chelonariidae Blanchard 1845, in: American Beetles, Volume 2. Polyphaga: Scarabaeoidea through Curculionoidea, edited by: Arnett Jr., R. H., Thomas, M. C. Skelley, P. E., and Frank, J. H., CRC Press LLC, Boca Raton, Fl., 139141, 2002.

Kirejtshuk, A. G. and Azar, D.: Current knowledge of Coleoptera (Insecta) from the Lower Cretaceous Lebanese amber and taxonomical notes for some Mesozoic groups, Terrestrial Arthro- 
pod Reviews, 6, 103-134, https://doi.org/10.1163/1874983606021061, 2013.

Kirejtshuk, A. G. and Ponomarenko, A. G.: Catalogue of fossil Coleoptera, available at: http://www.zin.ru/Animalia/ Coleoptera/rus/paleosys.htm (last access: 15 September 2020), 2014.

Klebs, R.: Über Bernsteineinschlüsse in allgemeinen und die Coleopteren meiner Bernsteinsammlung, Schriften der Physikalisch-ökonomischen Gesellschaft zu Königsberg in Pr., 51, 217-242, 1910.

Larsson, S. G.: Baltic amber - a palaeobiological study. Volume 1, Scandinavian Science Press Ltd., Klampenborg, 1978.

Latreille, P. A.: Tableau méthodique des insectes, in: Nouveau dictionnaire d'histoire naturelle, appliquée aux arts, principalement à l'agriculture et à l'economie rurale et domestique, Tome XXIV, Paris, Déterville, 129-200, 1804.

Leschen, R. A. B. and Early, J.: New collection of Brounia thoracica (Coleoptera: Chelonariidae), The Weta, 27, 15-21, 2004.

Mandl, K.: Chelonarium vartianae spec. nov. Österreichische entomologische Expedition nach Persien und Afghanistan. Teil VI: Byrrhidae, Annalen des Naturhistorischen Museums in Wien, 70, 443-444, 1967.

Méquignon, A.: Sur les Chelonarium des Antilles avec descriptions d'espèces nouvelles [Col. Byrrhidae], Bulletin de la Société entomologique de France, 37, 243-246, 1932.

Mitchell, J., Barbi, M. and Larsson, H. C. E.: Chelonarium andabata Alekseev et Bukejs sp. nov., holotype, RSKM P3000.141 [RSKM], X-ray micro-CT volume rendering of the habitus, TIB, https://doi.org/10.5446/49584, 2021a.

Mitchell, J., Barbi, M., and Larsson, H. C. E.: Chelonarium andabata Alekseev et Bukejs sp. nov., holotype, RSKM P3000.141 [RSKM], X-ray micro-CT volume rendering of the habitus (without legs), TIB, https://doi.org/10.5446/49583, 2021 b.

Mitchell, J., Barbi, M., and Larsson, H. C. E.: Chelonarium andabata Alekseev et Bukejs sp. nov., holotype, RSKM P3000.141 [RSKM], X-ray micro-CT volume rendering of the antennae, TIB, https://doi.org/10.5446/49582, 2021c.
Mitchell, J., Barbi, M., and Larsson, H. C. E.: Chelonarium andabata Alekseev et Bukejs sp. nov., holotype, RSKM P3000.141 [RSKM], X-ray micro-CT volume rendering of the aedeagus, TIB, https://doi.org/10.5446/49581, 2021d.

Paulus, H. F.: Pseudochelonarium (Neochelonarium) kalimantanense n.sp. aus Borneo, mit Bemerkungen zum System der Chelonariidae (Col., Dryopoidea), Zeitschrift der Arbeitsgemeinschaft Österreichischer Entomologen, 21, 105-109, 1969.

Poinar, G. O. and Rasmussen, F. N.: Orchids from the past, with a new species in Baltic amber, Bot. J. Linn. Soc., 183, 327-333, https://doi.org/10.1093/botlinnean/bow018, 2017.

Pütz, A., Hernando, C., and Ribera, I.: A new genus of Limnichidae (Coleoptera) from Baltic amber, Insect Systematics \& Evolution, 35, 329-334, https://doi.org/10.1163/187631204788920257, 2004.

Satô, M.: Remarkable new species of the genus Chelonarium (Coleoptera, Chelonariidae) from Borneo, Elytra, Tokyo, 29, 315-317, 2001.

Satô, M.: Family Chelonariidae C. É. Blanchard, 1845, in: Catalogue of Palaearctic Coleoptera. Volume 3, ScarabaeoideaScirtoidea-Dascilloidea-Buprestoidea-Byrrhoidea, revised and updated Edn., edited by: Löbl, I. and Löbl, D., Brill, Leiden/Boston, 623 pp., 2016.

Ślipiński, S. A., Leschen, R. A. B., and Lawrence, J. F.: Order Coleoptera Linnaeus, 1758, in: Animal Biodiversity: An Outline of Higher-level Classification and Survey of Taxonomic Richness, edited by: Zhang, Z.-Q., Zootaxa, 3148, 203-208, https://doi.org/10.11646/zootaxa.3148.1.39, 2011.

Wheeler, W. M.: The ants of the Baltic amber, Schriften der Physikalisch-ökonomischen Gesellschaft zu Königsberg in Pr., 55, 1-142, 1915.

Wickham, H. F.: New Miocene Coleoptera from Florissant, Bulletin of the Museum of Comparative Zoology, Harvard College, 53, 423-494, 1914. 